The Wages of Affluence 



\section{The Wages of Affluence}

Labor and Management in Postwar Japan

Andrew Gordon

Harvard University Press

Cambridge, Massachusetts

London, England

1998 
Copyright (C) 1998 by the President and Fellows of Harvard College All rights reserved

Printed in the United States of America

Library of Congress Cataloging-in-Publication Data

Gordon, Andrew, 1952-

The wages of affluence : labor and management in postwar Japan / Andrew Gordon.

p. $\mathrm{cm}$.

Includes bibliographical references and index.

ISBN 0-674-80577-1 (cloth : alk. paper)

1. Industrial relations-Japan-History - 20th century.

2. Labor policy_Japan-History-20th century. I. Title.

HD8726.5.G56 1998

$331^{\prime} .0952-\mathrm{dc} 21$

98-18610 
For Jennifer and Megumi 
